\title{
HP wt Allele
}

National Cancer Institute

\section{Source}

National Cancer Institute. HP wt Allele. NCI Thesaurus. Code C51250.

Human HP wild-type allele is located in the vicinity of $16 \mathrm{q} 22.1$ and is approximately $6 \mathrm{~kb}$ in length. This allele, which encodes haptoglobin protein, is involved in both the prevention of iron loss in the kidney and in the protection of damage in the kidney. 